\title{
Apatites Deficient in Divalent Cations
}

\author{
Aaron S. Posner ${ }^{1}$ and Alvin Perloff
}

\begin{abstract}
The preparation and results of a study of stoichiometric and divalent cation-deficient (defect) lead and calcium hydroxyapatites are reported. X-ray diffraction and index-ofrefraction data show that it is possible to have divalent cations missing from "columnar" positions in the hydroxyapatite structure, with possible hydrogen bonding in proper proportion for electrical neutrality. A general formula for apatites is suggested to be $\mathrm{D}_{10-x} \mathrm{M}_{2 x}\left(\mathrm{PO}_{4}\right)_{6}(\mathrm{OH})_{2}$, where $\mathrm{D}$ represents the divalent cation $\left(\mathrm{Pb}^{+2}, \mathrm{Ca}^{+2}\right.$, $\mathrm{Mg}^{+2}$, etc.) and M the monovalent cation, such as $\mathrm{Na}^{+}$and $\mathrm{H}^{+}$, and the upper limit of $x$ is probably 2 . It is suggested that the apatite portion of bone and tooth mineral may be some form of defect apatite.
\end{abstract}

\section{Introduction}

A number of finely divided calcium phosphates give the $\mathrm{X}$-ray diffraction pattern of hydroxyapatite, $\mathrm{Ca}_{10}\left(\mathrm{PO}_{4}\right)_{6}(\mathrm{OH})_{2}$, but depart from the ideal $\mathrm{Ca} / \mathrm{P}$ ratio of this mineral. (The formulas in this paper are given for unit-cell contents.) Examples are to be found in the inorganic portions of some bone and teeth, the mineral phosphorites, and the chemically precipitated synthetic apatites $[1,2,3] .{ }^{2}$ There are two conflicting explanations for a low $\mathrm{Ca} / \mathrm{P}$ ratio in certain high-surface-area hydroxyapatites. The first states that an excess of phosphate ions is adsorbed on the surface of tiny crystals of stoichiometric hydroxyapatite $[3,4]$. The second explanation postulates a statistical absence of calcium ions from structural positions throughout the crystal $[5,6] .^{3}$ In this case, electrical neutrality is probably obtained by the inclusion of protons present as hydrogen bonds between oxygens of orthophosphate groups ordinarily bonded to the missing calcium.

This paper presents data to support the latter theory and enlarges this view to include apatites containing other divalent cations, such as lead ions. These compounds, with imperfect $\mathrm{Ca} / \mathrm{P}$ (or $\mathrm{Pb} / \mathrm{P}$ ) ratios, are referred to as defect apatites. In this usage, this crystallographic term implies that certain space-group positions normally containing divalent cations $(\mathrm{Ca}, \mathrm{Pb})$ are statistically unoccupied.

\section{Adsorption Theory}

Many workers have said that the large surface area of the chemically precipitated, "apparently nonstoichiometric" hydroxyapatites can accommodate excess phosphate ions neutralized by some adsorbed cation $[3,4]$. If this were true, it is reasonable to assume that the surface exchange of phosphorus compared to calcium would be higher than the over-all $\mathrm{Ca} / \mathrm{P}$ ratio. Using radioisotopes, Weikel and Neuman [7] indicated that this was not true. The differences in chemical analysis of apatites studied could not be correlated to the surface composition. According to this work, the low $\mathrm{Ca} / \mathrm{P}$ apatite did not

Research Associate at the National Bureau of Standards, representing the American Dental Association.

2 Figures in brackets indicate the literature references at the end of this paper

3 Section 6.7 evaluates a slightly different postulate in which the ions are missing from crystal surface positions only [1]. show more phosphate surface exchange than the normal $\mathrm{Ca} / \mathrm{P}$ apatite.

A few simple calculations can shed serious doubt upon the surface-adsorption theory. In the case of any apatite, to lower the divalent cation to phosphorus molar ratio from $10 / 6$ to $9 / 6$, there must be an adsorption of 0.67 mole of phosphate per mole of apatite [8]. Considering each tetrahedral $\mathrm{PO}_{4}$ group as a sphere of radius $2.96 \mathrm{~A}$, the effective area occupied on the apatite surface by each $\mathrm{PO}_{4}$ group would be $27.53 \mathrm{~A}^{2}$.

Because $1 \mathrm{~g}$ of apatite is about $10^{-3}$ mole, then $0.67 \times 10^{-3}$ mole of surface phosphate ion would be needed for $1 \mathrm{~g}$ of this compound. Therefore, $1 \mathrm{~g}$ of apatite would require a surface area of $111.1 \mathrm{~m}^{2}$ to accommodate the above amount of phosphate $\left(27.53 \times 10^{-20} \times 6.02 \times 10^{23} \times 0.67 \times 10^{-3}=111.1 \mathrm{~m}^{2} / \mathrm{g}\right)$. If the surface diminished below this value, the phosphate could not be adsorbed in great enough quantity to lower the $\mathrm{Ca} / \mathrm{P}$ to $9 / 6$ from $10 / 6$. Both defect calcium hydroxyapatite and defect lead hydroxyapatite have been prepared with large enough crystal sizes to insure a maximum surface area far too small to account for the lowering of the metal to $\mathrm{PO}_{4}$ molar ratio by adsorption of excess phosphate. This discussion has been oversimplified and does not take into account the crystal surface needed to accommodate any cations that may be associated with the adsorbed phosphate ions.

\section{Preparations and Experimental Methods}

A series of calcium and lead apatites, with both ideal and defect divalent cation content, were prepared. The calcium compounds prepared ranged in $\mathrm{Ca} / \mathrm{P}$ weight ratio from the theoretical ratio of 2.15 down to 1.82. The two samples of lead apatite prepared had, respectively, the theoretical $\mathrm{Pb} / \mathrm{P}$ ratio of 11.10 and the "nonstoichiometric" ratio of 10.03 .

\subsection{Calcium Apatite}

The low $\mathrm{Ca} / \mathrm{P}(1.82)$ (sample 6 , table 1) apatite was prepared according to Arnold [9]. A liter of 0.1molar $\mathrm{CaCl}_{2}$ was mixed with about 7 liters of 0.1 molar $\mathrm{Na}_{2} \mathrm{HPO}_{4}$ and stirred for 2 days at room temperature. The solid was filtered, washed free of $\mathrm{Cl}^{-}$ and $\mathrm{Na}^{+}$, dried at $110^{\circ} \mathrm{C}$ for $24 \mathrm{hr}$, and analyzed chemically. 
The apatitic calcium phosphate with $\mathrm{Ca} / \mathrm{P}$ ratio of 1.94 (sample 5) was prepared by the method of Dallemagne [10]. A saturated solution of $\mathrm{Ca}(\mathrm{OH})_{2}$ was added to a solution consisting of $4 \mathrm{ml}$ of $85-$ percent $\mathrm{H}_{3} \mathrm{PO}_{4}$ in 4 liters of water until the pink end point of phenolphthalein was visible. Filtering and drying $\left(110^{\circ} \mathrm{C}, 24 \mathrm{hr}\right)$ yielded a defect apatite whose molar ratio was $9 \mathrm{Ca}$ to $6 \mathrm{P}$.

The other calcium compounds, which had $\mathrm{Ca} / \mathrm{P}$ ratios 2.08, 2.11, and 2.15 (samples 4,3 , and 1 , respectively), were all a result of the Wallaeys [11] procedure for the preparation of synthetic apatites. The method is similar to the above Dallemagne method, but after neutralization of the acid solution by $\mathrm{Ca}(\mathrm{OH})_{2}$, the $\mathrm{H}_{3} \mathrm{PO}_{4}$ solution is boiled and neutralized at the boiling temperature by the same method. If the neutralization point is reached, the product is an apatite of theoretically correct $\mathrm{Ca} / \mathrm{P}$ ratio (2.15). By falling short of the neutralization point at boiling temperatures, the lower $\mathrm{Ca} / \mathrm{P}$ values of 2.11 and 2.08 were obtained.

Another method was used to obtain stoichiometric calcium hydroxyapatite (sample 2) [12]. Pure crystalline $\mathrm{CaHPO}_{4}$ was prepared and hydrolyzed to hydroxyapatite with distilled water in a platinumlined hydrothermal bomb. This method vielded larger crystals than the Wallaeys preparation.

\subsection{Lead Apatites}

Pure lead apatite $\left[\mathrm{Pb}_{10}\left(\mathrm{PO}_{4}\right)_{6}(\mathrm{OH})_{2}\right]$ (sample 7) was made by placing $8 \mathrm{ml}$ of $0.5-M$ lead acetate solution in a platinum-lined hydrothermal bomb and slowly pipetting $4 \mathrm{ml}$ of $0.6-M\left(\mathrm{NH}_{4}\right)_{2} \mathrm{HPO}_{4}$ solution onto the first layer. Care was taken to maintain a two-layer system. The bomb was sealed and held at $300^{\circ} \mathrm{C}$ for 7 days, at which time the system. was quenched rapidly in water. The resulting well-crystallized solid was collected by filtration, after which it was washed in water, then in acetone.

A commercial lead phosphate (Fischer Scientific L.5), which had a molar Pb-to- $\mathrm{P}$ ratio of 8.9 to 6 and gave the X-ray pattern of lead apatite, served as a sample of defect lead hydroxyapatite (sample 8). According to the manufacturer, it was prepared by mixing solutions of tribasic sodium. phosphate and lead nitrate and decanting the supernatant liquid. The precipitate was washed with distilled water by decantation until the test for nitrate and sodium. was negative. The material was then filtered and dried $\left(110^{\circ} \mathrm{C}, 24 \mathrm{hr}\right)$.

In all the analyses: (a) calcium was determined volumetrically by titration of the oxalate with a standard potassium permanganate solution [13], (b) phosphorus was determined colorimetrically by the heteropoly blue method [14], and (c) lead was determined gravimetrically as $\mathrm{PbSO}_{4}$.

\subsection{Bomb Growth}

The chemically precipitated apatites are usually finely divided materials yielding X-ray diffraction patterns with broadened maxima. In two cases the apatite crystal size was increased by hydrothermalbomb growth [15, 18].
Two grams of low $\mathrm{Ca} / \mathrm{P}$ calcium apatite (sample 5 ' were introduced into the platinum-lined chamber $o^{f}$ the bomb and covered with $4 \mathrm{ml}$ of distilled water. The bomb was sealed with a platinum gasket and inserted into a furnace at $300^{\circ} \mathrm{C}$ for 7 davs. The resulting solid was filtered, washed, and dried, and designated as sample 5a.

In the case of the lead sample, $0.52 \mathrm{~g}$ of sample 8 and $10 \mathrm{ml}$ of distilled water constituted the bomb charge. The bomb was held at $300^{\circ} \mathrm{C}$ for 8 days; the sample was removed by filtration and designated as sample 8a.

In both cases the solid phase did not change in chemical analysis after the bomb treatment. In the case of the calcium apatite growth the bomb water showed only trace quantities of calcium and phosphate ions.

\subsection{Physical Measurements}

The average indices of refraction of the preparations were obtained by using oil-immersion techniques with the polarizing microscope. X-ray powder diffraction studies were carried out on a proportional-counter X-ray spectrogoniometer, using nickel-filtered copper K-radiation, taking special precautions in preparing the sample to avoid crystal orientation.

In the detailed X-ray study of the line intensities of the two lead apatite samples, a digital recorder was attached directly to the X-ray scaler and set to print out the integrated intensity every $10 \mathrm{sec}$. Because the spectrogoniometer traveled at $0.2^{\circ} 2 \Theta$ per minute, a 10 -sec print-out corresponded to an integration over a range of $0.033^{\circ} 2 \theta$. The intensity of each diffraction maximum was calculated from the digital information appearing on the adding-machine tape print-out system.

\section{Results}

Table 1 presents the results obtained for the calcium apatites.

It is possible to calculate by the method of Lorentz and Lorenz [16] the theoretical change in average index of refraction as calcium ions are removed statistically from structural positions. Figure 1 compares the variation in average index of refraction in calcium apatite as the $\mathrm{Ca} / \mathrm{P}$ is varied by missing calcium ions (data for sample 2 omitted).

Table 2 presents the results of the studies on the lead apatites. Included in the table is a comparison of the observed and calculated index of refraction for both the stoichiometric and defect materials. The Gladstone-Dale [17] method was used for these calculations.

The X-ray diffraction patterns of the calcium apatite samples were all very similar. As reported earlier [8], there is a slight tendency for the unitcell volume to shrink as the $\mathrm{Ca} / \mathrm{P}$ ratio falls. However, the relative intensities of the maxima do not change appreciably with changing calcium content. On the other hand, there are detectable differences in the relative intensities and spacings of the X-ray 
TABLE 1. Data obtained from the synthetic, calcium apatite series

\begin{tabular}{|c|c|c|c|c|}
\hline \multirow{2}{*}{ Sample } & \multicolumn{2}{|c|}{$\mathrm{Ca} / \mathrm{P}$} & \multirow{2}{*}{$\begin{array}{l}\text { A verage index } \\
\text { of refraction }\end{array}$} & \multirow{2}{*}{$\begin{array}{l}\text { X-ray } \\
\text { pattern }\end{array}$} \\
\hline & Weight & Molar & & \\
\hline $\begin{array}{l}1 \\
2 \\
3 \\
4 \\
5 \\
5 \mathrm{a} \ldots \ldots \\
6 \ldots \ldots\end{array}$ & $\begin{array}{l}2.15 \\
2.15 \\
2.11 \\
2.08 \\
1.94 \\
1.94 \\
1.82\end{array}$ & $\begin{array}{r}10.0 / 6.0 \\
10.0 / 6.0 \\
9.8 / 60 \\
9.7 / 6.0 \\
9.0 / 6.0 \\
9.0 / 6.0 \\
8.5 / 6.0\end{array}$ & $\begin{array}{l}\text { 1. } 635 \pm 0.005 \\
\text { 1. } 645 \pm 0.005 \\
\text { 1. } 625 \pm 0.005 \\
\text { 1. } 615 \pm 0.005 \\
\text { 1. } 600 \pm 0.005 \\
\text { 1. } 600 \pm 0.005 \\
1.582 \pm 0.005\end{array}$ & $\begin{array}{c}\text { Hydroxyapatite. } \\
\text { Do. } \\
\text { Do. } \\
\text { Do. } \\
\text { Do. } \\
\text { Do. } \\
\text { Do. }\end{array}$ \\
\hline
\end{tabular}

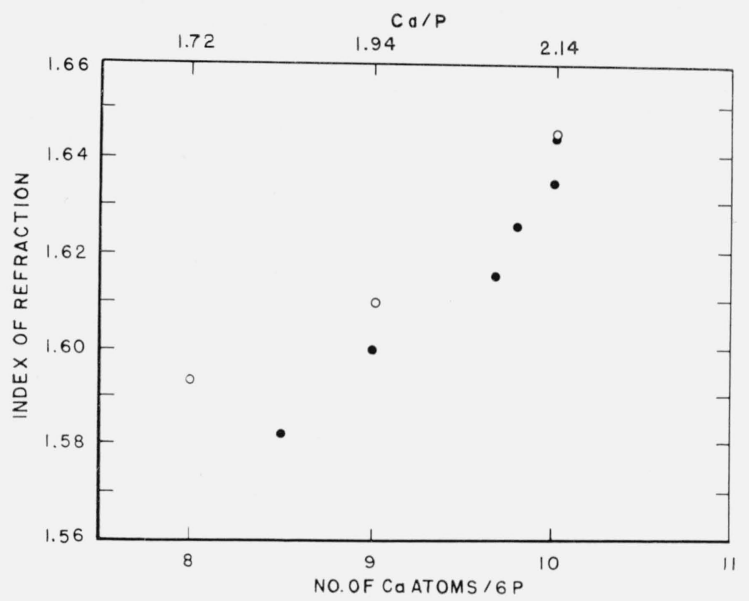

Figure 1. Change in average inder of refraction with $\mathrm{Ca} / \mathrm{P}$ ratio.

The open circles are the theoretical values calculated by the method of Lorentz and Lorenz [16]. The solid circles are the observed data.

TABLE 2. Data obtained from the synthetic, lead apatite series

\begin{tabular}{|c|c|c|c|c|c|}
\hline \multirow{2}{*}{ Sample } & \multicolumn{2}{|c|}{$\mathrm{Pb} / \mathrm{P}$} & \multicolumn{2}{|c|}{$\begin{array}{l}\text { A verage index of } \\
\text { refraction }\end{array}$} & \multirow{2}{*}{ X-ray pattern } \\
\hline & Weight & Molar & Observed & $\begin{array}{l}\text { Calcu- } \\
\text { lated }\end{array}$ & \\
\hline $7 \ldots \ldots$ & 11. 10 & $10.0 / 6.0$ & 2. $022 \pm 0.005$ & 2. 023 & Lead apatite. \\
\hline $8 \ldots$ & 10.03 & $8.9 / 6.0$ & $\begin{array}{l}1.992 \pm 0.005 \\
1.992 \pm 0.005\end{array}$ & $\begin{array}{l}1.995 \\
1.995\end{array}$ & $\begin{array}{l}\text { Modified lead } \\
\text { apatite. } \\
\text { Do. }\end{array}$ \\
\hline
\end{tabular}

patterns of normal lead apatite and defect lead apatite. The following study is based on these differences. A complete X-ray diffraction powder pattern of stoichiometric lead apatite will be published in a future section of National Bureau of Standards Circular 539, Standard X-ray diffraction powder patterns.

\section{X-ray Study}

\subsection{Stoichiometric Lead Apatite}

The powder pattern of lead apatite (table 4) was found to be in good agreement with earlier reports $[18,19]$. A structural analysis of the data was performed to see if the fluorapatite parameters were suitable for lead apatite. Because so many of the X-ray maxima of this complicated structure represent the superimposition of many independent reflections, the X-ray analyses in this work were carried out by using the relative-intensity values rather than the structure factors.

The space group of apatite is $\mathrm{C}_{6 \mathrm{~h}}^{2}\left(\mathrm{P} 6_{3} / \mathrm{m}\right)$. The atomic parameters assumed were taken from $\mathrm{S}$. Naray-Szabo [20] except for the $x$-axis parameter of $\mathrm{P}$, which was suggested by C. A. Beevers as an improved value (private communication).

TABLE 3. Atomic parameters of the asymmetric unit of the unit cell of fluorapatite applied to lead hydroxyapatite

\begin{tabular}{|c|c|c|c|c|}
\hline \multirow{2}{*}{ Atom } & \multirow{2}{*}{$\begin{array}{l}\text { Number } \\
\text { per unit } \\
\text { cell }\end{array}$} & \multicolumn{3}{|c|}{ Parameters in fraction of axis length } \\
\hline & & $x$ & $y$ & $z$ \\
\hline $\begin{array}{l}\mathrm{Pb} \mathrm{I} \ldots \\
\mathrm{Pb} \text { II } \\
\mathrm{OH} \\
\mathrm{O} \mathrm{I} \\
\mathrm{O} \text { II } \\
\mathrm{O} \text { III } \\
\mathrm{P}\end{array}$ & $\begin{array}{r}4 \\
6 \\
2 \\
6 \\
6 \\
12 \\
6\end{array}$ & $\begin{array}{r}0.333 \\
.250 \\
.000 \\
.333 \\
.600 \\
.333 \\
\mathrm{a} .390\end{array}$ & $\begin{array}{r}0.667 \\
.000 \\
.000 \\
.500 \\
.467 \\
.250 \\
.360\end{array}$ & $\begin{array}{r}0.000 \\
.250 \\
.250 \\
.250 \\
.250 \\
.063 \\
.250\end{array}$ \\
\hline
\end{tabular}

a Beevers' value; all others from Naray-Szabo [20].

Using the parameters in table 3 , the structure factors, and in turn the theoretical intensities for the observed X-ray maxima, were calculated. Comparing the observed and the calculated intensities of the first eight reflections (table 4), one arrives at a reliability factor of 21.8 percent. This is good agreement for intensity (as opposed to structure factor) comparisons, and the atomic parameters of fluorapatite are acceptable for this powder diffraction study of lead apatite. The employment of the multiple-index, higher-order reflections would have added little change to the reliability factor.

TABLE 4. Comparison of the observed and calculated X-ray diffraction intensities for the powder pattern of lead apatite

\begin{tabular}{|c|c|c|c|c|}
\hline Line & $h k l$ & $\begin{array}{c}\text { Observed } \\
\text { intensity a }\end{array}$ & $\begin{array}{l}\text { Calculated } \\
\text { intensity a }\end{array}$ & $I_{\mathrm{o}}=I_{\mathrm{c}}$ \\
\hline $\begin{array}{l}1 \\
2 \\
3 \\
4 \\
5 \\
6 \\
7 \\
7\end{array}$ & $\begin{array}{r}110 \\
200 \\
111 \\
002 \\
102 \\
120 / 210 \\
211 / 121 \\
112 \\
300\end{array}$ & $\begin{array}{r}270 \\
1,134 \\
1,226 \\
238 \\
1,169 \\
1,306 \\
5,658 \\
1,510\end{array}$ & $\begin{array}{r}346 \\
1,291 \\
1,734 \\
263 \\
1,688 \\
1,392 \\
4,248 \\
1,483\end{array}$ & $\begin{array}{r}-76 \\
-157 \\
-508 \\
-25 \\
-519 \\
-16 \\
+1,410 \\
+27\end{array}$ \\
\hline \multicolumn{5}{|c|}{$\begin{array}{l}\text { Reliability factor }(R)=\frac{\Sigma\left|I_{\mathrm{o}}-I_{\mathrm{c}}\right|}{\Sigma I_{\mathrm{o}}}, \\
R=\frac{2,738}{12,511}=0.218 .\end{array}$} \\
\hline
\end{tabular}

a Scale factor obtained from ratio of $\Sigma I_{\mathrm{o}}$ and $\Sigma I_{\mathrm{e}}$. This scale factor differs from that used in table 6 for comparing $I_{0}$ and $I_{10}$ 


\subsection{Defect Lead Apatite}

The four $\mathrm{Pb}$ I (columnar) atoms are stacked in two columns in the cell interior on the threefold rotation axes parallel to the $c$-axis. The six $\mathrm{Pb}$ II (hexagonal-screw) atoms are found associated with the hydroxyl ions, which are located on the hexagonalscrew axes parallel to the $c$-axis. Figure 2 diagrams a projection of the atoms of lead apatite upon the basal (001) plane. Figure 3 is the same projection with only the lead atoms shown.

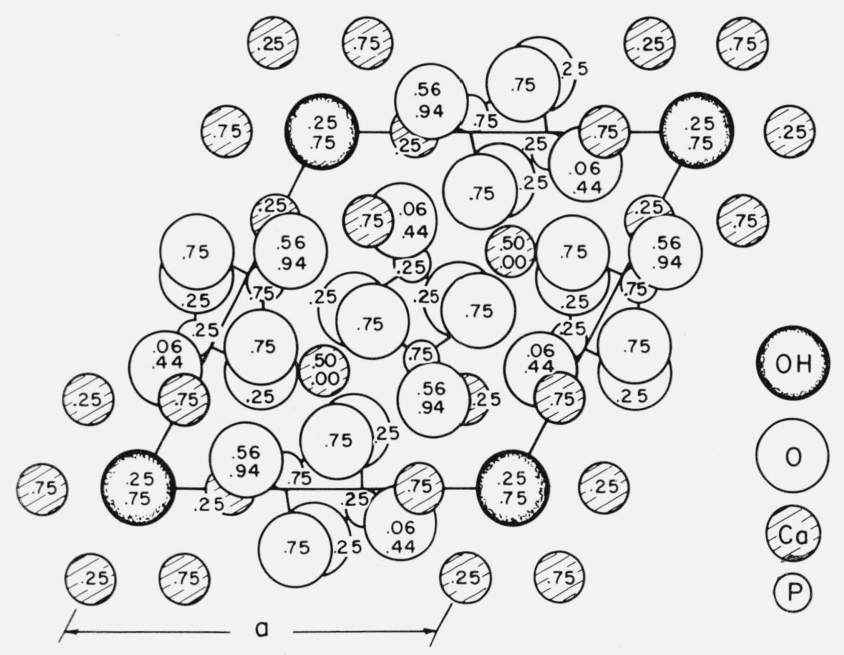

Figure 2. Projection down the c-axis onto the 001 plane of the hydroxyapatite structure.

The values withiz the atoms represent the height in the $c$-axis direction in fractions of this axis. The lead ions in lead apatite appear at same positions as the calcium ions in hydroxyapatite.

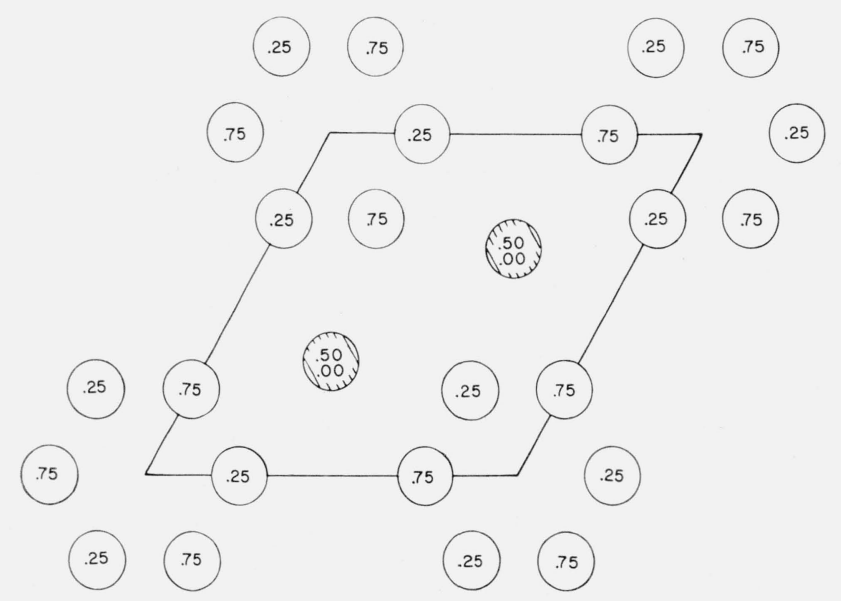

Figure 3. Same prcjection of hydroxyapatite as figure 2, showing only the divalent cations ( $\mathrm{Pb}, \mathrm{Ca}$, etc.).
The molar Pb-to-P ratio in the sample studied was 8.9 to 6 , but for simplicity of calculation, it was assumed to be 9 to 6 , with one lead ion missing per unit cell. This cation may be absent in three different ways: (a) missing statistically from all possible cation positions; (b) 1 of the $4 \mathrm{~Pb}$ I atoms may be missing statistically; or (c) 1 of the $6 \mathrm{~Pb}$ II atoms may be missing statistically. There is also the possibility that a specific cation is missing in each unit cell, but the lack of X-ray evidence of a superlattice made this improbable, and the possibility was ignored. Because the above parameters were found acceptable for lead apatite, the structure factors for reflections out to $\sin \theta / \lambda=0.471 \quad(\lambda=1.5405)$ were calculated for the above possible arrangements and for ideal lead apatite.

Table 5 lists the observed and calculated ${ }^{4}$ intensities for the first 23 reflections of the defect apatite. As can be seen, the over-all reliability factors for the four possibilities are all reasonable. This is not surprising because the majority of the reflections are little changed by a missing lead ion. Table 6 summarizes the difference between observed and calculated intensity values of these eight most strongly affected reflections. There is no question that case (b), in which one of the four $\mathrm{Pb}$ I atoms is missing per unit cell (table 6, last column), is the best match.

\section{Discussion}

\subsection{Lead Apatite}

The X-ray data obtained from defect lead apatite indicates that the cation is missing statistically from the $\mathrm{Pb}$ I structural position (fig. 3). Thus, in the case of a " $\mathrm{Pb}_{9}: \mathrm{P}_{6}$ " apatite, 1 of 4 cations located on the trigonal axes (i. e., $\mathrm{PbI}$ ) is missing per unit cell, with the defect statistically distributed through the 4 positions.

This corroborates the index-of-refraction data for lead apatite given in table 2. The observed drop in index of refraction is as expected, with one lead atom missing from the structure. Index-of-refraction data alone can merely suggest a missing cation per unit cell. The X-ray data identifies the exact nature of the defect structure. Recall that the problem was simplified by assuming one $\mathrm{Pb}$ ion missing per unit cell. Actually, the chemical analysis of the nonstoichiometric apatite indicated that there was a defect of 1.1 lead atoms per unit cell. This emphasizes the point that statistical absences of cations in such a structure need not be in discrete numbers. This is well illustrated by the calcium apatite series.

\subsection{Calcium Apatite}

The index-of-refraction data (fig. 1) show that the calcium series parallels the lead apatite case. As more cations are removed, the observed index drops. It is not surprising that the X-ray patterns of stoichiometric and all the nonstoichiometric calcium

${ }^{4}$ Calculated for the above three cases, (a), (b), and (c), as well as for the case where all 10 ions are present. 
TABLE 5. Comparison of the observed X-ray powder dala on defect lead apatite with the calculated intensities for the four possible cases

\begin{tabular}{|c|c|c|c|c|c|c|c|c|c|c|}
\hline Line & $h k: l$ & ${ }^{\mathrm{a}} I_{\mathrm{o}}$ & ${ }^{\mathrm{b}} I_{10}$ & $\left|I_{10}-I_{0}\right|$ & $\mathrm{c}_{9}^{\mathrm{st}}$ & $\left|I_{9}^{\mathrm{st}}-I_{\mathrm{o}}\right|$ & $\mathrm{d} I_{\rho}^{1 / 6}$ & $\left|I_{9}^{1 / 6}-I_{\mathrm{o}}\right|$ & $\mathrm{e} I_{9}^{1 / 4}$ & $\left|I_{9}^{1 / 4}-I_{0}\right|$ \\
\hline $\begin{array}{l}1 \\
2 \\
3\end{array}$ & $\begin{array}{l}110 \\
200 \\
111\end{array}$ & $\begin{array}{r}1.7 \\
41.7 \\
69.6\end{array}$ & $\begin{array}{r}9.7 \\
52.2 \\
72.9\end{array}$ & $\begin{array}{r}8.0 \\
10.5 \\
3.3\end{array}$ & $\begin{array}{r}9.1 \\
50.9 \\
68.4\end{array}$ & $\begin{array}{l}7.4 \\
9.2 \\
1.2\end{array}$ & $\begin{array}{l}18.3 \\
56.1 \\
58.1\end{array}$ & $\begin{array}{l}16.6 \\
14.4 \\
11.5\end{array}$ & $\begin{array}{r}1.6 \\
49.1 \\
91.7\end{array}$ & $\begin{array}{r}0.1 \\
7.4 \\
22.1\end{array}$ \\
\hline $4 \ldots$ & $\begin{array}{l}002 \\
201\end{array}$ & 26.1 & 14. 1 & 12.0 & 15.3 & 10.8 & 9.2 & 16.9 & 29.7 & 3.6 \\
\hline $5 \ldots$ & 102 & 87. 2 & 106. 7 & 19.5 & 105.1 & 17.9 & 114.9 & 27.7 & 101. 6 & 14. 4 \\
\hline $6 \ldots$ & $\begin{array}{l}210 \\
120\end{array}$ & 111.5 & 96.3 & 15.2 & 94.6 & 16.9 & 103.6 & 7.9 & 91.3 & 20.2 \\
\hline $7 \ldots$ & $\begin{array}{l}211 \\
121\end{array}$ & 585.8 & 364.0 & 221.8 & 362.8 & 223.0 & 387.9 & 197.9 & 368.8 & 217.0 \\
\hline $8 \ldots$ & $\begin{array}{l}112 \\
300\end{array}$ & 154.4 & 142.1 & 12.3 & 143.6 & 10.8 & 165.1 & 10.7 & 127.7 & 26.7 \\
\hline $\begin{array}{l}9 \\
10\end{array}$ & $\begin{array}{l}202 \\
301\end{array}$ & $\begin{array}{l}2.1 \\
1.8\end{array}$ & $\begin{array}{l}5.0 \\
0.3\end{array}$ & $\begin{array}{l}2.9 \\
1.5\end{array}$ & $\begin{array}{l}6.2 \\
0.3\end{array}$ & $\begin{array}{l}4.1 \\
1.5\end{array}$ & $\begin{array}{r}12.4 \\
0.3\end{array}$ & $\begin{array}{r}10.3 \\
1.5\end{array}$ & $\begin{array}{l}1.1 \\
0.3\end{array}$ & $\begin{array}{l}1.0 \\
1.5\end{array}$ \\
\hline $11 \ldots$ & 220 & 2.3 & 8.8 & 6.5 & 8.4 & 6.1 & 16.4 & 14.1 & 1. 7 & 0.6 \\
\hline $12 \ldots$ & $\begin{array}{l}212 \\
122 \\
103\end{array}$ & 2.5 & 2. 6 & 0.1 & 3.2 & 0.7 & 7.0 & 4.5 & 4. 7 & 2.2 \\
\hline $13 \ldots$ & $\begin{array}{l}310 \\
130\end{array}$ & 8.1 & 8.6 & .5 & 10. 6 & 2.5 & 9.4 & 1.3 & 17.1 & 9.0 \\
\hline $14 \ldots$ & 221 & 1.0 & 0.8 & .1 & 1.1 & 0.1 & 1.2 & 0.2 & 1.1 & 0.1 \\
\hline $15 \ldots$ & $\begin{array}{l}311 \\
131 \\
302\end{array}$ & 14.2 & 19.4 & 5.2 & 19.2 & 5. 0 & 34.7 & 20.5 & 6.5 & 7.7 \\
\hline $16 \ldots$ & 113 & 87.6 & 106. 7 & 19.1 & 107.7 & 20.1 & 97.4 & 9.3 & 134. 3 & 46.7 \\
\hline 17. & $\begin{array}{l}203 \\
400\end{array}$ & 50.5 & 39.2 & 11.3 & 36.9 & 13.6 & 27.0 & 23.5 & 63.7 & 13.2 \\
\hline $18 \ldots$ & $\begin{array}{l}222 \\
401\end{array}$ & 221.1 & 375.2 & 154.1 & 379.1 & 158.0 & 284.3 & 63.2 & 220.5 & 0.6 \\
\hline $19 \ldots$ & $\begin{array}{l}312 \\
132 \\
320\end{array}$ & 151.1 & 185.4 & 34.3 & 185.3 & 34.2 & 201.7 & 50.6 & 179.6 & 28.5 \\
\hline $20 \ldots$ & $\begin{array}{l}230 \\
123 \\
213\end{array}$ & 311.1 & 314.3 & 3. 2 & 318.3 & 7.2 & 306.5 & 4.6 & 370.7 & 59.6 \\
\hline $21 \ldots$ & $\begin{array}{l}321 \\
231\end{array}$ & 216.3 & 188.5 & 27.8 & 189.5 & 26.8 & 172.0 & 44.3 & 237. 2 & 20.9 \\
\hline $22 \ldots$ & $\begin{array}{l}303 \\
410\end{array}$ & 192.3 & 185.6 & 6.7 & 184.1 & 8.2 & 213.2 & 20.9 & 161.2 & 31.1 \\
\hline $23 \ldots$ & $\begin{array}{l}140 \\
402\end{array}$ & 390.0 & 433.9 & 43.9 & 433.0 & 43. 0 & 436.1 & 46.1 & 471.4 & 81.4 \\
\hline
\end{tabular}

${ }^{a} I_{0}=$ Observed relative intensity.

${ }^{\mathrm{b}} I_{10}=$ Calculated relative intensity for all 10 lead ions present.

${ }^{\mathrm{c}} I_{9}^{\mathrm{st}}=$ Calculated relative intensity for one lead ion per unit cell missing statistically from all possible positions.

$\mathrm{d} I_{9}^{1 / 6}=$ Calculated relative intensity for 1 lead ion per unit cell missing statistically from the 6 hexagonal-screw positions.

e $I_{9}^{1 / 4}=$ Calculated relative intensity for 1 lead ion per unit cell missing statistically from the 4 columnar positions.

TABLE 6. Abstract of table 5, showing the X-ray intensities most affected by the missing lead atoms

\begin{tabular}{|c|c|c|c|c|}
\hline \multirow{2}{*}{$\mathrm{X}$-ray line } & \multicolumn{4}{|c|}{$\begin{array}{l}\text { Defect lead apatite } \\
\qquad\left(I_{\mathrm{o}}-I_{\mathrm{c}}\right)\end{array}$} \\
\hline & $I_{0}-I_{10}$ & $I_{\mathrm{o}}-I_{9}^{\mathrm{st}}$ & $I_{\mathrm{o}}-I_{9}^{1 / 6}$ & $I_{\mathrm{o}}-I_{9}^{1 / 4}$ \\
\hline $\begin{array}{l}1 \\
2 \\
4 \\
9 \\
11 \\
15 \\
17 \\
18\end{array}$ & $\begin{array}{r}-80 \\
-105 \\
120 \\
-29 \\
-65 \\
-52 \\
113 \\
-1541\end{array}$ & $\begin{array}{r}-74 \\
-92 \\
108 \\
-41 \\
-61 \\
-50 \\
136 \\
-1580\end{array}$ & $\begin{array}{r}-166 \\
-144 \\
169 \\
-103 \\
-141 \\
-205 \\
235 \\
-632\end{array}$ & $\begin{array}{r}1 \\
-74 \\
36 \\
10 \\
6 \\
77 \\
-132 \\
6\end{array}$ \\
\hline
\end{tabular}

apatites are so similar. A calculation of the effect of a missing $\mathrm{Ca}$ ion per unit cell indicated no measurable change. The high atomic number of lead as compared to calcium results in a greater change in the X-ray intensities when 1 in 10 atoms is missing.

It is fortunate that the missing calcium atoms do not affect the crystalline unit-cell volume appreci- ably. As the number of calcium atoms per unit cell declines, it is inevitable that the index of refraction falls, because the unit-cell volume is reduced only slightly. The lack of exact match between calculated and observed indices of refraction in the calcium apatite series is probably due to the inexact nature of the molecular refractivities assumed for the Lorentz-Lorenz calculation. It is important to note the parallel nature of the drop in index of the observed and theoretical apatites as the calcium content of the unit cell is reduced. It seems reasonable that a defect apatite series exists in the case of calcium with cations missing from columnar positions as in the lead compounds. Here, too, the calcium ions are probably absent statistically from the four unit-cell positions on the trigonal axes and not in any integral number per unit cell.

An earlier study [8] showed that the observed density of a calcium-defect hydroxyapatite (with $\mathrm{Ca} / \mathrm{P}=9 / 6$ ) was 2.89 , as opposed to 3.13 for pure hydroxyapatite. This is the value predicted by assuming the missing calcium mechanism. It serves to corroborate the index-of-refraction data presented above. 


\subsection{Hydrogen Bonds}

Electrical neutrality in these low-cation apatites can be achieved by the inclusion of hydrogen ions as hydrogen bonds in the proper proportion. It is not reasonable to place two protons in a lattice position previously occupied by a lead or calcium ion. The hydrogen probably enters into the structure as a hydrogen bond between the oxygens of adjacent orthophosphate tetrahedra. It is not possible to prove this hypothesis with the present $\mathrm{X}$-ray data. Future single-crystal studies with $\mathrm{X}$-ray and neutron diffraction will be needed to further establish this suggested mechanism of achieving neutrality.

One can envision these apatites with missing cations as hybrids between the acid and basic orthophosphate structures. In the calcium series the structure of hydroxyapatite is quite different from $\mathrm{CaHPO}_{4}$ or $\mathrm{CaHPO}_{4} \cdot 2 \mathrm{H}_{2} \mathrm{O}[21,22]$, and it is unlikely that a continuous solid-solution series exists between apatite and either of the latter compounds. There must be a lower limit to the amount of missing cation in the nonstoichiometric series for, as the $\mathrm{Ca} / \mathrm{P}$ atomic ratio approaches unity, there will be alterations in the crystal structure. In the synthetic calcium apatite system, the lowest $\mathrm{Ca} / \mathrm{P}$ ratio reported to date is $8 / 6[9,23,24]$. Whether this is the limit or not is unknown at this writing. All attempts to precipitate apatites with $\mathrm{Ca} / \mathrm{P}$ ratios lower than $8 / 6$ by the authors and others $[9,24]$ have resulted in the formation of an acid phosphate phase.

\subsection{Evidence for Hydrogen Bonds}

An interesting series of experiments $[25,26]$ has given some experimental evidence for the presence of hydrogen in defect calcium apatite. The calcium uptake from saturated $\mathrm{Ca}(\mathrm{OH})_{2}$ solution by finely divided "low-calcium" apatites was observed by chemical analysis of the solid and conductivity measurements in the solution. Higher temperatures resulted in an increased calcium uptake, and the amount of calcium chemically bound (i. e., Ca not removed by washing) always brought the $\mathrm{Ca} / \mathrm{P}$ of the solid to $10 / 6$, the ratio for pure apatite. ${ }^{5}$ In all cases the conductivity of the $\mathrm{Ca}(\mathrm{OH})_{2}$ solution dropped further than the Ca loss would require. It is feasible that the hydrogen leaving the apatite when calcium returns to the empty cation position (either by diffusion or recrystallization) will form poorly ionized $\mathrm{H}_{2} \mathrm{O}$, thus altering the conductivity expected by only considering the Ca loss. Neuman [27] confirms this by showing a lowering of the $p \mathrm{H}$ in solution when calcium is added to "basic calcium phosphates" (another term for low-calcium apatites). He reports this to be due to the release of $\mathrm{H}_{3} \mathrm{O}^{+}$as the calcium ions return to the defect sites (see section $6.7)$.

${ }^{5}$ Samples dried at room temperature gave $10.5 / 6$ as the final chemically bound $\mathrm{Ca} / \mathrm{P}$ ratio.

\subsection{Nomenclature}

In light of the probable hydrogen bonding it is not completely correct to refer to these compounds as nonstoichiometric hydroxyapatites. The more precise term defect apatite is thus employed.

As in other complicated series of compounds, the hydroxyapatite "family" is best characterized by a general formula. This might be $\mathrm{D}_{10-x} \mathrm{M}_{2 x}\left(\mathrm{PO}_{4}\right)_{6}(\mathrm{OH})_{2}$, where $\mathrm{D}$ represents the divalent cation $\left(\mathrm{Ca}^{++}\right.$, $\left.\mathrm{Pb}^{++}, \mathrm{Sr}^{++}\right)$and $\mathrm{M}$ the monovalent cation $\left(\mathrm{Na}^{+}\right.$, $\mathrm{H}^{+}$, etc.). In the case of the defect lead apatite given above, the formula becomes $\mathrm{Pb}_{8 \cdot 9} \mathrm{H}_{2 \cdot 2}\left(\mathrm{PO}_{4}\right)_{6^{-}}$ $(\mathrm{OH})_{2}$. A sodium substituted apatite would have the general formula $\mathrm{D}_{10-x} \mathrm{Na}_{x} \mathrm{H}_{x}\left(\mathrm{PO}_{4}\right)_{6}(\mathrm{OH})_{2}$, where $\mathrm{Na}$ can occupy the divalent cation positions in the lattice with hydrogen bonding effecting electrical neutrality. This paper does not deal with possible isomorphous substitutions for phosphate and hydroxyl ions.

\section{6. "Octocalcium Phosphate"}

Arnold [9] suggested a mechanism to explain the calcium-deficient hydroxyapatites that he prepared. He postulated that as many as 2 of the 4 columnar calcium ions per unit cell could be missing to form octocalcium phosphate, an apatite with a $\mathrm{Ca} / \mathrm{P}$ ratio of $8 / 6$. To achieve this stoichiometry and maintain the structural symmetry of apatite, Arnold proposed that all the hydroxyl groups are missing, whereas the calciums (missing at the same columnar c-level) are replaced by water, and that hydrogen ions are in some way associated with the columnar calciums that are present. His theory allows for a series ranging between this low-calcium apatite and pure apatite. He suggests that octocalcium phosphate is an infinite two-dimensional complex, $\mathrm{Ca}_{4} \mathrm{H}\left(\mathrm{PO}_{4}\right)_{3} \cdot 3 \mathrm{H}_{2} \mathrm{O}$, with sheets held together by hydrogen bonds between the oxygens in the $\mathrm{PO}_{4}$ groups and the oxygens of the water molecules. As more columnar calcium is taken up, Arnold feels that hydrogen would be randomly eliminated, resulting in ionic bonding between the sheets.

Even though Arnold's viewpoint superficially resembles the theory of defect apatites presented in this paper, it is actually quite different. He recognized the need for an explanation of low-calcium apatites, but his mechanism must be rejected on a few simple grounds. First, it seems unlikely that the apatite structure will hold together with the hydroxyl ions missing. Granting that such a structure were possible, the removal of the $\mathrm{OH}^{-}$ions from their special positions would result in measurable changes in the relative intensity of many of the X-ray diffraction maxima. In addition, the mechanism of water substitution for columnar calcium between the "sheets" would certainly result in expanded unit-cell constants. Such changes in the apatite X-ray patterns of these low-calcium materials have not been demonstrated. Arnold [24] and Engström [25] reported certain low-angle, "nonapatite" X-ray maxima in the study of octocalcium phosphate that 
could not be fully explained. Segerman (private communication) observed similar low-angle X-ray reflections in studying dental calculus. He suggested they may be due to an ordered loss of calcium ions in the columnar position, resulting in an apatite superlattice. If this can be clearly demonstrated, it will add further proof to the existence of calciumdeficient hydroxyapatites. In addition, such a mechanism may provide the structural link between the hydrogen-containing orthophosphates and the basic orthophosphates.

Besides the lack of X-ray diffraction corroboration, Arnold's theory does not correctly predict the observed index-of-refraction data. If missing calcium ions are supplanted by water, the index of refraction of low-calcium apatites will not drop as observed (fig. 1). Thus, Arnold's hypothesis, although provocative, is felt to be incorrect.

\subsection{Calcified Tissue}

The major phase of the inorganic portion of bone and teeth is generally accepted to be a low $\mathrm{Ca} / \mathrm{P}$ form of hydroxyapatite [1]. Neuman and Neuman [1], in a very thorough review article on the mineral portion of bone, offer a concept to explain this lack of stoichiometry in bone apatite. Adopting Arnold's view that water can replace calcium in the apatite structure (see section 6.6), they postulate missing calcium ions supplanted by hydronium ions $\left(\mathrm{H}_{3} \mathrm{O}^{+}\right)$ on the surface of the tiny apatite crystals in bone. Because the surface in bone-apatite crystals represents such a large proportion of the solid, the average $\mathrm{Ca} / \mathrm{P}$ of the material is thereby lowered. Like the Arnold theory, this view of nonstoichiometry in bone apatite is open to question on the basis of index of refraction and X-ray diffraction results (section 6.2 ).

The theory of Neuman and Neuman depends entirely upon a small crystal size in the same way as the phosphate-adsorption theory discussed in section 2. In contradiction to this, it is possible to prepare lead defect and calcium defect apatites with low specific areas (section 3.3). According to Neuman and Neuman, the particle size of a boneapatite crystal will dictate the $\mathrm{Ca} / \mathrm{P}$ stoichiometry. In the results reported above (section 3.4), there is no correlation between crystal size (from X-ray diffraction line broadening) and $\mathrm{Ca} / \mathrm{P}$ ratio.

Surface-exchange experiments on a calcium defect apatite $(\mathrm{Ca} / \mathrm{P}=9 / 6)$ showed that about 5 percent of the total calcium was found on the crystal surface [27]. Because 10 percent of the total calcium ions were postulated to be missing from surface positions, 15 percent of all the calcium positions in the crystal would have to be on the surface. Such a crystal would require a specific surface of about $200 \mathrm{~m}^{2}$, or at least three times the value reported for the above defect apatite with 5 percent of exchangeable calcium [27].

Bone-apatite crystals range in size from about $25 \mathrm{~A}$ to about $1,500 \mathrm{~A}$, with an average diameter of about 200 to $300 \mathrm{~A}$ [28]. The surface-substitution mechanism could only explain the calcium defects in the 25- to 100-A region because larger crystals cannot furnish the surface needed for this postulated effect. It seems improbable that the defects should exist only on the surface for smaller crystals and be distributed throughout the material for larger crystals.

It is probable that the apatites in bone and tooth mineral are isostructural with the synthetic, lowcalcium apatites described in this paper. It is further suggested that these biological apatites can take up calcium (and other ions that can isomorphously substitute for calcium) from the body fluids and release hydrogen ions previously found as hydrogen bonds in the solid. The differences in stoichiometry found in various specimens of bone and tooth salt may be related to changes effected by exposure to serum containing ions $\left(\mathrm{Ca}^{++}, \mathrm{Mg}^{++}\right.$, $\mathrm{Sr}^{++}, \mathrm{Sn}^{++}$, etc.) that react with defect apatites.

\section{Summary}

Methods of preparation of both stoichiometric and defect lead and calcium hydroxyapatites are discussed.

X-ray diffraction data are given to verify the use of the fluorapatite parameters for lead apatite in structure-factor calculations.

The existence of defect lead hydroxyapatite and calcium hydroxyapatite is supported with X-ray diffraction and index-of-refraction data. An analysis of the X-ray data for cation-defective lead apatite indicates the lead ions to be missing statistically from the "columnar" positions.

With divalent cations missing from positions in the unit cell, the electrical neutrality of apatite is postulated to be obtained by hydrogen bonding between oxygens of the orthophosphates surrounding the defects.

A general formula for apatites of this type is suggested to be $\mathrm{D}_{10-x} \mathrm{M}_{2 x}\left(\mathrm{PO}_{4}\right)_{6}(\mathrm{OH})_{2}$, where $\mathrm{D}$ is the divalent cation $\left(\mathrm{Pb}^{+2}, \mathrm{Ca}^{+2}, \mathrm{Mg}^{+2}\right.$, etc. $)$ and $\mathrm{M}$ is the monovalent cation $\left(\mathrm{H}^{+}\right.$and $\left.\mathrm{Na}^{+}\right)$. The upper limit of $x$ is unknown but present results suggest that this value is about 2 .

It is quite probable that the apatite portion of bone and tooth mineral is identical to the synthetic, defect apatites described herein.

\section{References}

[1] W. F. Neuman and M. W. Neuman, Chem. Revs. 53, 1 (1953)

[2] A. S. Posner, M. J. Dallemagne, and C. Fabry, J. Physiol. (Paris) 46, 325 (1954).

[3] S. B. Hendricks and W. L. Hill, Proc. Nat. Acad. Sci. U. S. 36, 731 (1950).

[4] W. F. Bale, M. L. LeFevre, and H. C. Hodge, Naturwess. 24, 636 (1936).

[5] A. S. Posner, Proc. Int. Union Pure and Appl. Chem., Inorganic Section, Münster (1954).

[6] A. S. Posner, C. Fabry, and M. J. Dallemagne, Biochim. et Biophys. Acta 15, 304 (1954).

[7] J. H. Weikel, and W. F. Neuman, U. S. Atomic Energy Report UR 228 (1952).

[8] A. S. Posner and S. R. Stephenson, J. Dental Research 31, 371 (1952). 
[9] P. W. Arnold, Trans. Faraday Soc. 46, 1061 (1950).

[10] M. J. Dallemagne, J. Physiol. (Paris) 43, 425 (1951).

[11] R. Wallaeys, Thesis, Univ. Paris (1952).

[12] A. Perloff and A. S. Posner, Science 124, 583 (1956).

[13] F. F. Tisdall and B. J. Kramer, J. Biol. Chem. 48, 1 (1921).

[14] D. F. Boltz and M. J. Mellon, Anal. Chem. 19, 873 (1947).

[15] G. W. Morey and E. Ingerson, Am. Mineralogist 22, 1121 (1937).

[16] H. A. Lorentz, Wiedem. Ann. 9, 641 (1880); L. Lorenz, Wiedem. Ann. 9, 70 (1880).

[17] J. H. Gladstone and T. P. Dale, Roy. Soc. (London) Phil. Trans. 153, 337 (1863).

[18] R. Klement, Z. anorg. u. allgem. Chem. 237, 161 (1938)

[19] M. Müller, Helv. Chim. Acta 30, 2069 (1947).
[20] S. Naray-Szabo, Z. Krist. 75, 387 (1930)

[21] G. MacLennen and C. A. Beevers, Acta Cryst. 8, 579 (1955).

[22] C. A. Beevers and B. Raistrick, Nature 173, 542 (1954).

[23] R. Warington, J. Chem. Soc. 19, 296 (1866).

24] D. Carlström, Acta Radiol. Suppl. 121 (1955).

[25] C. Fabry, Biochim. et Biophys. Acta 14, 401 (1954).

[26] C. Fabry, J. Physiol. (Paris) 46, 361 (1954).

[27] W. F. Neuman, U. S. Atomic Energy Report UR 238 (1953).

[28] M. L. Watson and R. A. Robinson, Anat. Record 114, 383 (1952).

Washington, December 27, 1956. 